\title{
STAT6 Gene
}

National Cancer Institute

\section{Source}

National Cancer Institute. STAT6 Gene. NCI Thesaurus. Code C24835.

This gene plays a role in signal transduction and activation of transcription. 